\title{
SOCIAL CONTROL OF WOMEN'S BODY AS CULTURAL-POLITICAL LEGITIMATION IN “PUTRI CINA” NOVEL
}

\author{
Resa Sartika $^{1 *}$; Dwi Susanto²; Prasetyo Adi Wisnu Wibowo³ \\ ${ }^{1-3}$ Cultural Studies Department, Universitas Sebelas Maret \\ Jl. Ir. Sutami No. 36, Kentingan, Surakarta, Jawa Tengah 57126, Indonesia \\ 1'resaeka.sartika@gmail.com; ${ }^{2}$ dwisastra81@gmail.com; ${ }^{3}$ prasetyoadiwisnuwibowo@yahoo.co.id
}

Received: $22^{\text {nd }}$ January 2021/ Revised: $06^{\text {th }}$ April 2021/ Accepted: $06^{\text {th }}$ April 2021

How to Cite: Sartika, R., Susanto, D., \& Wibowo, P. A. W. (2021). Social control of women's body as
cultural-political legitimation in “Putri Cina” novel. Humaniora, 12(2), 151-159.
https://doi.org/10.21512/humaniora.v12i2.6972

\begin{abstract}
The research aimed to describe the depiction of the female body's domination as a form of political-cultural legitimacy raised in Sindhunata's work entitled Putri Cina. Michel Foucault's theory of discourse was applied as the approach to reveal how sexuality was closely related to power practices. The discourse presented in the novel was dissected by qualitative methods, descriptive qualitative, and interpretative data analysis techniques. The results show that the two main characters of this novel are Chinese women who experienced oppression in Java. The existence of a cultural identity crisis, abjection, passivity, and not subversion represents the figure of alienated women. This perspective is intertwined with how indigenous men perceive Chinese women figures. Sindhunata describes the unequal construction of sexuality between men and women and the discrimination of the Chinese race as repeated during the kingdom era, pre-independence, to the New Order era.
\end{abstract}

Keywords: social control, discrimination, female body, cultural legitimation, political legitimation

\section{INTRODUCTION}

The Chinese ethnic group has often become the target of hatred on numerous occasions. This phenomenon has happened since the Dutch colonization of Indonesia. Before the Dutch arrived in Indonesia, the Chinese had already arrived in Indonesia to trade. Their relations with the natives were equal to trading partners. However, these relations were destroyed due to the arrival of the Dutch in Indonesia.

In October 1740, there was turmoil in Chinatown when both the Dutch and natives massacred the ethnic Chinese in Batavia. According Dhani (2016), this incident took the lives of up to 10.000 people, and about 7.000 Chinese homes were looted and burned. This incident was not the only bloody moment for the Chinese ethnic group in Indonesia. During the Java War in September 1825, the daughter of Sultan Hamengkubuwono I, namely Raden Ayu Yudakusuma, and her troops attacked Ngawi. On their way to Ngawi, they killed Chinese people, both women and children.

Another one of the mass rampage moments towards ethnic Chinese in Indonesia was the tragedy of May 1998. The types, causes, actions, policies of the authorities, and other mass rampage patterns towards ethnic Chinese in the May 1998 tragedy were not much different from the patterns at the moment of the previous mass rampage. This pattern indicates that the hatred towards ethnic Chinese is socially constructed by the authorities from the Dutch or VOC government, the Javanese kingdoms, and the Indonesian government. The hatred that has been created is ultimately ingrained and widespread without any reconciliation or clear explanation. During the New Order era, the hatred towards ethnic Chinese could not be separated from the Indonesian government's political strategy at that time.

Freedman (2003) has stated that this hatred of the ethnic Chinese is caused by Soeharto's split political strategy. It is stated that Soeharto forced the Chinese community to assimilate and identify them as 'different' from indigenous Indonesian groups. Soeharto's split political strategy is outlined in several regulations at the level of state law. The tragedy of 
May 1998 is one of the great moments of mass anger against ethnic Chinese due to the legacy of the New Order's divisions' political strategy. On 23 June 1998, a BBC article stated that there were reports of sexual violence against Chinese women during the 1998 riots. The victims who were afraid to reveal this incident finally dared to speak up and talk about sexual violence experienced by Chinese women. As stated in the BBC article in 1998, rioters broke into homes, raped women, and even killed very young victims. The sexual violence experienced by Chinese women has even occurred in front of their families and neighbors. The government denied what happened to these ethnic Chinese women. Until finally, President B.J. Habibie's apology was made to the families of victims of sexual violence on 15 July 1998.

Chinese women experience double oppression due to the stereotypes attached to Chinese ethnicity and their gender. Stereotypes or negative labeling are detrimental, and it causes injustice as well (Novitasari, 2018). The stereotypes attached to Chinese women have caused them to become vulnerable to sexual violence, such as rape. The violence experienced by Chinese women shows that women's bodies do not belong to women themselves, and it can be caused by the patriarchal culture, which has already manifested in the society's mindset (Fujiati, 2016). This patriarchal mindset has been entrenched in male dominance in Javanese culture. Besides, this dominance has also led to the idea that men are placed in the superior position, while women are often considered as the objects to satisfy men's sexual desire (Wijayanti, Hadi, Furinawati, 2018). This kind of thought shows that all this time, women's bodies do not belong to women themselves. Consequently, the patriarchal structure has led to sexual politics (Asfar, 2015).

The oppression against Chinese women is presented as the major discourse in a novel entitled Putri Cina written by Gabriel Possenti Sindhunata, also better known as Sindhunata. The incidents of sexual violence against Chinese women have inspired Sindhunata to write the novel. The novel is about Putri Cina (Chinese princess), a Chinese Peranakan woman who lives in Java. Sindhunata provides a narrative about the life of Chinese Peranakan in Java through a long historical journey that started from the era of the Majapahit Kingdom in the archipelago.

Sofia Kartika has also stated that the reality of society, especially concerning the lives of women depicted in literary works, could be events that happen in reality. This is due to the function of literary works to process the reality that exists in society into a material of self-reflection (Kartika, 2003)

The tragedy of May 1998 in Indonesia has inspired Sindhunata to write Putri Cina. As a descendant of the Chinese, Sindhunata wants to present the story in historical wrapping inspired by the tragedy in May 1998. Ethnic Chinese women are considered far more susceptible to oppression than other ethnic women because of deep-rooted racial sentiments. Through this novel, Sindhunata presents a social construction attached to women and their bodies, namely as a voiceless and submissive objectification, and the vulnerability faced by ethnic Chinese women to these social constructions.

Foucault (1972) is the first to introduce a way of looking at a social life without exception. According to Foucault (1972), language is a social construction where subjects play power for specific purposes. Foucault has assumed that there is no absolute truth in any discourse produced by humans because constructed truths always have biases for affirming the dominant cultural power. These subjects in this dominant culture create discourse by combining what Foucault calls the operation of power/knowledge, namely the cooperation of one's knowledge to operate power (Foucault in Udasmoro, 2018). In the Foucauldian method, discourse analysis holds at least three key elements: discourse, history, and power (Dhona, 2020).

Foucault (1978) has made sexuality relatable to other social phenomena. When drawn from history, sexuality is a collection of power, discourse, body, and affection. Due to the process of individualization and detraditionalization, sexuality has plural meanings and interpretations. It shows that sexuality is essential in determining moral values and health, desire, and identity. The maleness and femaleness are shaped into a discourse that becomes an absolute truth so that it is considered a natural thing. There is also normalization, which normalizes a concept, phenomenon, and situation, leading to inclusion and exclusion. Power as a discourse regime can reach, penetrate, and control individuals to the most intimate pleasures (Yasin, 2016).

In a book entitled Gender Trouble (1990), Judith Butler has revealed that gender is a constructed phenomenon. As a construction, gender is established through repeated and continuous performance and behavior. Consequently, it creates gender norms and terms such as masculinity and femininity. Butler has criticized that this gender norm puts identity in a rigid position that cannot be changed due to its relation to appropriateness. In fact, gender has a much broader spectrum than being categorized in a norm.

In social, cultural, and political contexts, women's sexuality is considered as a moral symbol of a community or even a nation. Besides, women's sexuality is also often treated as the scapegoat of existing moral problems. Therefore, regulations are created to manage the body so that it can be used. In this regulation, gender, ethnicity, class, and age group are taken into consideration in composing these rules. The body becomes the target of power and knowledge, and Foucault calls it as the docile body or the obedient body in which it can be used, transformed, and repaired.

In relation to religion and politics, women are often seen as commodities, both as representations of demonic temptations and a symbol of greed. Eventually, women lose authority over their own bodies since they are considered as a commodity. In 
a racial context, sexuality is used as a legitimacy of superiority among one race over another. For example, in the $19^{\text {th }}$ century, the black race was often considered as slaves of the white race. The women who are considered as the other are excluded from the grand narrative. Julia Kristeva calls the 'othering' of women an abjection, which literally means the condition of being expelled or discarded. This concept is applied by Kristeva to explain the narrative of discriminatory attitudes (Kristeva in Udasmoro, 2020). In this case, the discourse of sexuality is not a subordinate reality that is difficult to grasp, but rather a broad network on the surface where bodily stimulation, intensification of enjoyment, and the logical consequence of a strategy of knowledge and power (Abadi, 2017).

Oppression against ethnic Chinese is the central theme of the novel written by Sindhunata. The discourse on the control of the Chinese ethnic women's bodies will be a significant point in this research. This research will also focus on the culturalpolitical legitimacy of the control over the body of ethnic Chinese women in Sindhunata's Putri Cina.

This is certainly not the first research, which analyzes Putri Cina since previous researchers have already discussed Sindhunata's Putri Cina in their researches. Saputra (2011) has revealed that Putri Cina is a reflection of the identity discrimination issue in Indonesia, namely the Chinese in front of the Javanese. Zamzuri (2012) has analyzed the issue of identity between native and foreign (Chinese) as the effect of colonialism and racial oppression of Chinese descendants. This research shows that Sindhunata provides a perspective that China is not a foreign figure since it cannot be separated from the growth and development of Java.

Sakinah (2012) has discussed the representation of women in constructing women's identity and political issues. The role of Putri Cina shows that political issues in the process of ethnic assimilation have contributed to changes in the country. Meanwhile, Giok Tien's role in the process of ethnic assimilation is to contribute to the name of Javanese art, namely ketoprak. Sakinah's (2014) second research on Putri Cina has also examined the female characters in Putri Cina. In this research, Sakinah discusses the identity and political issues of the novel, which is seen from the orientalist side. This research mentions that identity is seen by women as an internal psychological and an external socio-cultural issue.

In her research, Dewi (2019) has aimed to show the relationship between texts and determine Putri Cina's position in the world of literature. The result shows that desire, revenge, and violence are often depicted through Putri Cina figures as the scapegoats for these three elements. This makes Putri Cina can be considered as the symbol of peace in the literary world due to her caring and loving nature. She seems to be the messenger of peace for the chaos happening in the country she has considered as home, although the chaos and cruelty will not easily vanish.

\section{METHODS}

The research is in the scope of cultural studies applying qualitative methods and descriptive, qualitative, and interpretive data analysis techniques. The qualitative method in the research does not only describe the literal meaning but also tries to find the hidden meaning. The qualitative method applied discourse analysis, an approach for studying discourse by focusing on the power and the powerful subjects. All aspects in social life included language, are socially constructed, in which subjects exercise power for specific purposes. Foucault assumes that there is no absolute truth in any discourse produced by humans because the constructed truths always have biases to strengthen the dominant culture's power (Foucault in Udasmoro, 2018).

The primary material object of the research is a novel written by Sindhunata entitled Putri Cina. Other material objects used are non-literary texts containing interviews with Sindhunata as the author of Putri Cina and other texts that support the discussion of the novel. The theory of gender and sexuality is applied as the major or grand theory in order to uncover the discourse on controlling ethnic Chinese women's bodies as cultural-political legitimacy in the novel. Meanwhile, the data collection methods used are document study and literature study.

In order to avoid misconceptions about the concepts discussed in the research, it is necessary to explain some of the concepts used. The first concept is ethnic Chinese. Ethnic Chinese are all immigrants and their descendants who live within the Indonesian culture scope and do not depend on citizenship, the language surrounding Chinese culture. They see themselves as Chinese or are considered as such by their environment. The second concept is the control of the female body. In social, cultural, and political contexts, women's sexuality is considered as a moral symbol of a community or even a nation. Besides, women's sexuality is also often treated as the scapegoat of existing moral problems. Therefore, regulations are created to manage the body so that it can be used. In this regulation, gender, ethnicity, class, and age group are taken into consideration in composing these rules. The body becomes the target of power and knowledge (Butler, 1990). Foucault calls it as the docile body or the obedient body in which it can be used, transformed, and repaired.

\section{RESULTS AND DISCUSSIONS}

The name Putri Cina in the novel does not refer to one character only. This name is mainly pinned to figures of Chinese Peranakan women who live in Java and come from reasonably wealthy families. In this novel, Putri Cina refers to two main characters. The first character is an ethnic Chinese woman whose real name is unknown and not mentioned. This woman is the wife of the last King of Majapahit, namely Prabu 
Brawijaya Fifth, and she is also the mother of Raden Patah. The second character is Giok Tien, an artist of Javanese ketoprak, who later becomes Senapati Gurdo Paksi. The two characters, who are labeled as Putri Cina (Chinese princesses), have their own stories, and their stories are not related. However, the stories of these two characters have some similarities; both of them are oppressed women in Java due to their Chinese ethnicity. Through these two characters of Putri Cina, Sindhunata describes how ethnic Chinese women are treated in Java.

This novel begins with an identity crisis experienced by the first character, Putri Cina. Putri Cina is indeed of Chinese descent. However, she knows nothing about the land of her ancestors since she has never been there before. Putri Cina has heard the story about the origin of her Chinese ancestors and their arrival to Java island. The story tells that the Chinese who sailed to Java island were the descendants of Jaka Prabangkara, the son of the concubine of King Brawijaya. This story indicates that Java island is also the homeland of the Chinese because their ancestors were born on Java island. Another story suggests that Putri Cina had set foot on Java island long before Jaka Prabangkara sent his descendants to sail to Java island. In the end, Putri Cina still does not know her origin. One thing is for sure, the possibility that the Chinese who lived in Java were also the descendants of Javanese does not change the fact that the Chinese remain alienated by indigenous people. They are considered as liyan or the others who are oppressed.

An important thing that should be highlighted from the story is that the first main character is only called by the name of Putri Cina and the real name of the wife of the Fifth King of Brawijaya remains unknown. This is also analogous to an expression stating that she has never seen her own beauty. Whenever she looks into the mirror, all she sees is a scorched rose. This analogy shows that the nickname Putri Cina symbolizes the melting of a woman's identity of Chinese descent over her ethnicity so that she is neither seen nor personally considered. Putri Cina feels that she is not accepted by the natives in Java, even though she has lived in Java and even married a king of Majapahit Kingdom, who is also known as the ruler of Java.

The existence of Putri Cina represents the othering of women, and it also represents women as subversive, passive, and powerless individuals. The passivity of Putri Cina seems to have become a natural trait for ethnic Chinese women in this novel, while in fact, this passivity is the result of oppression. The concept of abjection proposed by Julia Kristeva has also become very relevant. Moreover, Putri Cina literally experiences abjection since she is being expelled or banished. This status is related to the discriminatory conditions that befall ethnic Chinese women living in Java.

Cultural identity crisis is also experienced by other women in Putri Cina, namely Giok Tien. Giok Tien learns about Javanese art, and she becomes a successful ketoprak player who loves Javanese art.
Unfortunately, Giok Tien has a similar fate as Putri Cina because she is rejected by the Javanese due to her existence as a Chinese woman. Besides serving as an identity fuser, the name Putri Cina also describes the discrimination experienced by Chinese women. In the novel, Putri Cina has tried to fit into a complete Javanese, to the point that she is more Javanese than the Javanese themselves. However, the Javanese still call them Putri Cina. It implies that no matter how hard these Chinese women try to adopt the Javanese culture, they are still not entirely accepted by the Javanese and considered as the others due to their physical appearance and social status, which are different from the Javanese. The name Putri Cina becomes the cause of the cultural identity crisis experienced by Putri Cina and Giok Tien.

The meaning of Chinese women's beauty described in this novel is identical. The characters, who are called Putri Cina, are described as having beautiful faces, slanted eyes, small noses, thin lips, and fair complexion. In addition, they are also described as women who are desired by men due to their beauty and sexual anticipation.

The indigenous male characters in the novel are often depicted through their irrepressible sexual desire, which needs to be fulfilled. This irrepressible sexual desire is stated by Korsinah, saying that both Chinese and indigenous men often make women who play in ketoprak as their sexual fantasies. Since the beginning of the novel, men's lust has been described as an uncontrollable desire. Whenever powerful male characters meet beautiful and charming women, the depicted reaction is always related to their sexual desire, and the entire picture ends in a rape scene.

The depiction of sexuality in Putri Cina is still based on the assumption that sexuality is a process of heterosexual relationships that become part of the same instincts possessed by animals. This strong instinct must eventually be fulfilled, and in this novel, the form of channeling is through rape. This discourse leads to the unequal construction of sexuality between men and women, which is ultimately used as the legitimacy of men's domination over women.

The femininity discourse attached to both characters in Putri Cina is the discourse about passive and helpless women. This discourse becomes a norm that could not be shifted easily because of the position of Putri Cina as a minority citizen in Java. Besides, Putri Cina is also an ethnic Chinese woman who is oppressed by powerful men.

There is a scene experienced by Putri Cina that implies the life of ethnic Chinese women in Java. Putri Cina sees a group of children singing a song entitled Cucak Rowo, which later popularly sung in various corners. In the middle of the group, there is a cute man who brings a cage and Chinese potehi puppets. That cute man dresses up as a soldier, but he gradually takes off his entire clothes until he stays in his underwear. It can be said that the Cucak Rowo song actually depicts the violence experienced by Chinese women in their daily lives in Java. They are always in the grip of 
violence, like puppet potehi women in the hands of men who are dashing like soldiers but wearing only underwear. This violence is so natural that it no longer feels like a threat, especially because of the chanting of Cucak Rowo's song sung cheerfully by young children. This scene represents an expectation of how Chinese women are treated in Java, which then becomes the main narrative of the Putri Cina novel.

In the story, it is told that there are numerous disputes in Java. One of the disputes occurred during the time of the Kingdom of Pedang Kemulan (Medang Kamulan Baru), led by Prabu Amurco Sabdo. This dispute has made the Chinese, especially the women, become the victims. Rape scenes against ethnic Chinese women are also described:

"Even more horrified, his eyes seemed to be opened to see how Chinese women were running helter-skelter, being chased by men with halfnaked cropped hair. When finally grabbed, the men violently stripped the Chinese women, laid them down, and gave their lust to the fullest. Chinese women just screamed, cried, helpless." (Sindhunata, 2007: 119)

Giok Tien, who lived during the Kingdom of Pedang Kemulan, also experienced discrimination and sexual violence when the dispute occurred. She also witnesses her two elder sisters, Giok Hong and Giok Hwa, are killed by a group of masked men after being stripped naked and raped. Although Giok Tien was married to an indigenous man named Gurdo Paksi, Giok Tien and her two sisters are not free from discrimination and sexual violence. They remain a minority in the eyes of the natives.

Giok Tien is almost raped and murdered, but she is saved by a man named Joyo Sumengah. Joyo Sumengah is previously known as Radi Prawiro, and he gets his title after getting promoted. Unable to resist the beauty of Giok Tien, Joyo Sumengah tries to rape Giok Tien after saving her, and the helpless Giok Tien tries to seek help by screaming. It is described that Joyo Sumengah is not only overwhelmed by his lust but also the desire to take revenge on Giok Tien because of her rejection.

Giok Tien is then saved again by another man called Prabu Amurco Sabdo, who comes and stops the action from Joyo Sumengah. Prabu Amurco Sabdo warns him:

"You can be brought down by that hypocrisy, Joyo Sumengah. You can succeed in keeping things safe. However, if your behavior is tarnished by stealing the love of women, all your services will be destroyed, and you will become a defendant who violates immorality. You will be punished more severely for the offense than if you lose the power play." (Sindhunata, 2007: 235)

In addition to the above excerpt, there is also an expression in the novel that states that immorality is considered the most dropping than other actions such as cruelty and oppression of the people. This suggests that female sexuality indirectly determines the moral value of a person. Even in social, cultural, and political contexts, female sexuality is often regarded as a moral symbol of a community or even a nation. Moreover, it is stated by Prabu Amarco Sabdo himself, who is a king, where he occupies the highest social class in Java. Indirectly, women's bodies have been categorized as objectified, transformed, and improved to become docile or obedient bodies. All of this is done as if to maintain the moral values of a person or even a nation. In fact, the controlling of women's bodies makes women eventually lose authority over their own bodies, and it is also used as the legitimacy of superiority between men over women, or in this context, the superiority of indigenous men over the ethnic Chinese women.

The legitimacy becomes clearer when Prabu Amurco Sabdo, who has saved Giok Tien from the threat of Joyo Sumengah, is also tempted as well by the beauty of Giok Tien. Prabu Amurco Sabdo's hypocrisy is clearly stated:

"Looking at the thigh, there is no way a man's lust will not be torn apart." (Sindhunata, 2007: 244)

Butler in Gender Trouble (1990) has revealed that gender is a constructed phenomenon. In the quote, Prabu Amurco Sabdo shows the portrayal of sexuality as a strong and unstoppable instinct that must be channeled. This kind of sexual depiction creates unequal sexual construction between men and women. It can be seen from the use of the word 'menggagahi' (overpower) to replace the word 'memperkosa' (rape), which is previously used to describe forced sexual intercourse.

In bahasa Indonesia, the word 'menggagahi' comes from 'gagah' (dashing), which means strong, big, powerful, and noble. This shows that Butler has criticized that this gender norm places identity in a rigid position that cannot be changed because it is related to conformity. Butler has also mentioned that the body is the target of power and knowledge. The use of the word 'menggagahi' to replace the word 'memperkosa' (rape) indicates that forcing sexual intercourse against women who reject it can be considered as a pride for men. On the other hand, men will be humiliated if they are unable to sexually conquer women. The word 'menggagahi' makes sexuality ultimately act as a sign of power. Women are considered the object of power since some people consider that a man cannot be said as powerful if he cannot conquer the woman he wants. In the end, the body of ethnic Chinese women becomes a cultural and political legitimacy tool for the rulers.

Giok Tien is successfully saved from Joyo Sumengah's evil behavior, but she ends up being raped by Prabu Amurco Sabdo. She is like going out of the frying pan and into the fire, which literally means moving from a bad situation to an even worse one. 
This is similar to the abolition of the Sati ritual in India by the British colonial government (Spivak, 1988). Sati is a ritual of self-burning performed by Indian women whose husbands died. The ritual is performed by immersing themselves in the fire, burning the husband's dead body. The British colonial government considered the ritual as barbaric and banned it under the pretext of rescuing Indian women. However, at the same time, the British colonial government silenced Indian women and positioned them as objects which are exposed for political purposes and ongoing civilizational projects in India, as the Indian women were not allowed to give testimonials about Sati (Spivak, 1988). Just like the British colonial government, Prabu Amurco Sabdo seems to have saved Giok Tien from the threat of Joyo Sumengah, but on the other hand, he also raped Giok Tien as the legitimacy of his power and power as a king.

\begin{abstract}
"Thus, the lust for the woman before him stirred into one with the lust to defend and maintain his power. The lust then becomes so thundering, burrowing like fierce waves in the great ocean. It is no longer possible for him to hold and master it. His desire has become a desire that no longer wants to give in because, in that desire, it is no longer distinguishable, which is the power of male lust, which is the power to defend and declare his power as the ruler. The lust was after him. He became impetuous, pursued Giok Tien until he was gasping for breath. Giok Tien can be grasped. Passionately she took off Giok Tien clothing. Giok Tien screamed and rebelled, but to no avail." (Sindhunata, 2007: 250)
\end{abstract}

As mentioned earlier, these indigenous male characters show interest in Putri Cina characters in the form of lust. These indigenous male characters are indeed attracted to Putri Cina characters, but on the other hand, they also do not accept the Chinese as part of the natives. This indicates the tendency of indigenous men to feel superior and have more power than women, especially ethnic Chinese women. Thus, they feel that these Chinese women deserve to be considered as the object to fulfill their lust. These Chinese women characters are hailed for their beauty, but on the other hand, their beauty is considered a curse, as revealed by Giok Tien:

"Your Majesty, this country never has respected women. This country, which is ruled by men, denigrates women only as mere male pleasure targets. Nevertheless, in this country, men do not want to admit that it is what it is. They seem to respect and look after women, even though they only desire to marry women in the deepest part of their hearts. That is the hypocrisy of the land that you command." (Sindhunata, 2007: 265)

Various events regarding racial discrimination and violence against women's sexuality have ultimately inspired the authors in their literary works. This incident is inseparable from the view that a literary work is constructed not from mere emptiness but events surrounding the author's life (Artawan, Yasa, \& Darmayanti, 2014). Kartika (2003) has also stated that society's realities, especially those related to women's lives depicted in literary works, could be things that happen in the real world. The situation is due to literary works' function as the processing of reality in society into a material for self-reflection (Kartika, 2003).

Events of racial discrimination and violence against the sexuality of ethnic Chinese women have ultimately inspired Sindhunata as well to write Putri Cina's novel. As explained directly by Sindhunata during an interview, the tragedy of May 1998 has become his inspiration in writing the Putri Cina novel. Sindhunata also states that as a Chinese descendant in Indonesia, he wants to present this story in history. Thus, the novel's narrative is written through a long historical journey that started from the era of the Majapahit Kingdom in the archipelago.

In Putri Cina, Sindhunata emphasizes the various treatment received by ethnic Chinese women living in the archipelago. It is also mentioned that racial discrimination and sexual violence happened many times like a recurring pattern, both in the past and future. The event considered as the beginning of this pattern is the Geger Pecinan (Chinatown Commotion) that occurred in October 1740. During this event, both Dutch and natives looted and burned about 6.0007.000 Chinese homes. The death toll was estimated at 10.000 people. This Geger Pecinan tragedy is also emphasized several times in the novel. After Geger Pecinan, Sindhunata captures the story of an attack in Ngawi. During the Java War in September 1825, the daughter of Sultan Hamengkubuwono I, namely Raden Ayu Yudakusuma, and her troops attacked Ngawi. On their way to Ngawi, they killed Chinese people, both women and children.

At the beginning of the $20^{\text {th }}$ century, there were also racial incidents against ethnic Chinese, namely the riots in Solo in 1912 and Kudus in 1918. There were also other anti-ethnic Chinese movements during the revolution, such as in Tangerang from May to July 1946, Bagan Siapi-api in September 1946, and Palembang in January 1947. More recently, the tragedy of the ethnic Chinese community's massacre occurred in 1965 during the 1965-G30S conflict. The massacre followed 30.000 ethnic Chinese massacres in West Kalimantan Province in 1967 during the PGRS/ PARAKU conflict.

The following incident is the tragedy of May 1998, similar to the Geger Pecinan where Chinese descents were subjected to discrimination and even sexual violence. The tragedy of May 1998 was closely related to the regulations of the New Order era led by Suharto. The New Order government afflicted the majority of Chinese people with its discriminatory policies. However, on the other hand, a small group 
of Chinese people benefited and enjoyed various investment facilities so that they became a very wealthy upper class. This small group of facilitated Chinese people was ultimately regarded as representations of all ethnic Chinese. Looking at the historical background, the hatred constantly received by ethnic Chinese is actually a social construction made by the ruler, both from the Netherlands and Java. The hatred that has been created is ultimately ingrained and widespread without any reconciliation or clear explanation. The primordial ideas about indigenous people against ethnic Chinese people because they are considered cukong and extortion of local people's property become legitimacy for the natives to commit crimes.

The state laws and regulations issued during the Old Order Era and the New Order Era attempted to create common ground or unity of identity as an Indonesian nation, so that ethnic Chinese could not independently express their identity (Christian, 2017). In addition to exclusion within the legal framework under the state law, there were also a number of practices that excluded Chinese society. Some of these include restricting the Chinese from becoming Civil Servants (PNS), especially high military positions, and their involvement in politics. There were even quota restrictions for admission to State Universities (PTN) for Chinese people (Suryadinata, 2003).

An article released by BBC on 23 June 1998 disclosed that hundreds of ethnic Chinese women were raped during the riots in May 1998. The ethnic Chinese women who had not dared to speak up about this case finally came forward for the first time and told their story of sexual violence they experienced. According to the witnesses, the rioters broke into homes and raped the ethnic Chinese women and even the young girls. Tragically, these sexual acts of violence were done in front of their families. After raping these women, they would burn the house down. The perpetrators consisted of approximately ten men, some of whom had tattoos and were drunk.

The exact number of ethnic Chinese women who became the victim of sexual assault remains unknown since many of them had escaped from Indonesia, and the rest are still too traumatized to speak up and report it. Numerous victims also tried to commit suicide due to depression. Up until now, the perpetrators of this sexual violence have not been completely arrested and investigated. The state had consistently denied any rape allegations during the riots in May 1998. It was President B.J. Habibie who eventually admitted the sexual assault and followed it up by forming TGPF. The country's denials further assert the position of ethnic Chinese women as subalterns, namely oppressed or colonized or minority people or groups who do not have the capacity to express themselves because they are in a position of powerlessness under the control of power (Spivak, 1988).

Rape is often seen only as an excess of conflict or war. The losses suffered by female victims are judged to be disproportionate to material damage or destruction. The way of the view of rape is also experiencing its own debate from differences in the definition of rape itself to the debate over whether the rape is related to riots or not. This kind of debate is common in cases of mass rape because the data on this case relies heavily on reports from victims. However, it can be an obstacle because some victims do not want to report the case or do not want to report it (Green, 2004).

The mass rape during the tragedy of May 1998 is also emphasized by Sindhunata in the Putri Cina novel, where it occurred when a dispute arose during the Kingdom of the Pedang Kemulan. Just like the mass rape that occurred in the tragedy of May 1998, mass rape is also described in the Putri Cina novel. Giok Tien is said to have experienced the same thing, in which she witnesses the rape and murder of her two sisters in their own home before briefly fleeing to the Negeri Singa. Giok Tien herself is also the victim of a rape committed by Prabu Amurco Sabdo.

Women are often considered to belong to vulnerable groups that are often victims of structural violence. This is due to the intersection of their identities, such as gender, race, class, and religious identity, which makes them more vulnerable to becoming victims of violence. In a racial context, sexuality does serve as the legitimacy of superiority between races. In the context of gender, sexism and patriarchy have shaped the concept of rape, vulnerability, and marginalization of ethnic Chinese women. Gender as a social construction has created unequal gender norms between men and women, especially in the realm of sexuality (Butler, 1990).

One important concern is when family members are forced to watch their female family members being raped in the tragedy of May 1998. It is also depicted in Putri Cina when Giok Tien witnesses her two sisters being raped and murdered by rioters. This is a common act encountered in mass sexual assault in times of conflict. It aims to conquer and also feminine the victims and their communities. Forcing a family member to witness a female family member being raped is intended to make them feel weak by not being able to do anything to protect or help their family (Brown in Hikmawati, 2017).

Sexual violence experienced by women of ethnic Chinese in the May 1998 tragedy is often referred to as the climax of anti-Chinese violence. Due to their vulnerable and powerless position, the state carries out layered oppression as cultural-political legitimacy by using women's bodies as instruments.

\section{CONCLUSIONS}

Gabriel Possenti Sindhunata, also better known as Sindhunata, tries to present discourse about oppression against ethnic Chinese women outlined in the Putri Cina novel. Through Putri Cina and Giok Tien's characters, Sindhunata provides a narrative about Chinese Peranakan lives in Java. The tragedy 
of May 1998 has inspired Sindhunata to write Putri Cina. As a Chinese descendant living in Indonesia, he reveals that he wants to present the story in historical wrapping. Therefore, this novel is told through a long historical journey, which began when the Majapahit Kingdom was still in power in the archipelago.

In the Putri Cina novel, a common thread knits the similarities between Putri Cina and Giok Tien's story, namely oppression in racial and sexual discrimination or violence as an ethnic Chinese woman living in Java. The discrimination experienced by these two figures has caused a cultural identity crisis. No matter how hard the Putri Cina characters in this novel try to become Javanese, they are still not entirely accepted by the indigenous people because they are physically and socially different. This makes the characters of Putri Cina become the other or liyan who are powerless because they are often excluded from the grand narrative and under oppression, especially from powerful men.

The depiction of sexual violence in the novel Putri Cina is also told in sufficient detail, where the rape of ethnic Chinese women will always be present in every dispute that occurs in Java. The indigenous men in the novel show an interest in Putri Cina characters in the form of lust. They glorify the beauty of Putri Cina, but on the other hand, they also do not accept the Chinese as part of the indigenous community. This indicates the tendency of indigenous men to feel superior and powerful than women, especially ethnic Chinese women. Thus, they consider Chinese women merely objects to fulfill their sexual desire.

The depiction of unequal sexuality between men and women is described when Prabu Amurco Sabdo raped Giok Tien. The use of the word 'menggagahi' (overpower) to replace the word 'memperkosa' (rape) makes the existing discourse on sexuality not neutral. Another example of the layered representation of violence experienced by Chinese women in Java is the Cucak Rowo song, sung by children and men in soldier uniforms. This scene represents the violence experienced by women of ethnic Chinese in their daily lives. They are always in the grip of violence, but the violence itself is so natural that it is no longer considered a threat.

The racial discrimination and sexual violence experienced by ethnic Chinese women described in the Putri Cina novel by Sindhunata also occur in the real world. They started from the Geger Pecinan incident in October 1740 to events in a more modern context, namely the tragedy of May 1998. The hatred that the ethnic Chinese community living in Indonesia receives is a social construction made by the authorities. The hatred that has been created is ultimately ingrained and widespread without any reconciliation or clear explanation. During the New Order era, government policies and social practices made ethnic Chinese communities unable to freely express themselves and their culture. They were coupled with the New Order government policy, which gave privileges to a small group of ethnic Chinese people. This small ethnic Chinese group benefited and enjoyed various investment facilities to become the very wealthy upper class. This small group of Chinese people facilitated is ultimately considered a representation of all ethnic Chinese in Indonesia.

Social tension among indigenous peoples towards Chinese society also peaked during the Tragedy of May 1998. In addition to material destruction and looting, there was also sexual violence and rape to murder ethnic Chinese women. Like Sindhunata described in the novel Princess of China, rioters consisting of indigenous men broke into houses and raped ethnic Chinese women in front of their families.

Women are often considered to belong to vulnerable groups that are often victims of structural violence. In a racial context, sexuality does serve as the legitimacy of superiority between races. In the context of gender, sexism and patriarchy have shaped the concept of rape, vulnerability, and marginalization of ethnic Chinese women. Meanwhile, in social, cultural, and political contexts, women have always been the target of attack in conflict or war situations. They become the victims of sexual assault in order to destroy women's home communities as well.

\section{REFERENCES}

Abadi, H. S. (2017). Kekuasaan seksualitas dalam novel: Perspektif analisis wacana kritis Michel Foucault. Belajar Bahasa: Jurnal Ilmiah Program Studi Pendidikan Bahasa dan Sastra Indonesia, 2(2), 167178. https://doi.org/10.32528/bb.v2i2.828.

Artawan, I. G., Yasa, I. N., \& Darmayanti, I. A. M. (2014). Tubuh perempuan dalam teror patriarkhi. Seminar Nasional Riset Inovatif, 2, 648-655.

Asfar, D. A. (2015). Jangan main-main dengan kelaminmu: Antara wacana seksualitas dan feminisme. Mabasan, 9(1), 19-28. https://doi.org/10.26499/mab.v9i1.153.

BBC News. (1998). Ethnic Chinese tell of mass rapes. Retrieved on October 22 $2^{\text {nd }}, 2020$ from http:// news.bbc.co.uk/2/hi/events/indonesia/special report/118576.stm.

Butler, J. (1990). Gender trouble: Feminism and the subversion of identity. New York: Routledge.

Christian, S. A. (2018). Identitas budaya orang Tionghoa Indonesia. Jurnal Cakrawala Mandarin, 1(1), 1122. http://dx.doi.org/10.36279/apsmi.v1i1.11.

Dewi, N. (2019). Positioning the Chinese princess of peace in world literature. Jurnal Pendidikan Bahasa dan Sastra Indonesia, 4(1), 18-23. https://dx.doi. org/10.26737/jp-bsi.v4i1.905.

Dhani, A. (2016). Sejarah kebencian terhadap etnis Tionghoa. Retrieved on September 22 $2^{\text {nd }}, 2020$ from https://tirto.id/sejarah-kebencian-terhadap-etnistionghoa-bFLp.

Dhona, H. R. (2020). Analisis wacana Foucault dalam studi komunikasi. Journal Communication Spectrum: Capturing New Perspectives in Communication, 9(2), 189-208. 
Foucault, M. (1972). Archaeology of knowledge. New York: Pantheon Books.

Foucault, M. (1978). The history of sexuality. New York: Pantheon Books.

Freedman, A. (2003). Political institution and ethnic Chinese identity in Indonesia. Asian Ethnicity, 4(3), 439-452. http://dx.doi.org/10.1080/1343900032000 117259 .

Fujiati, D. (2016). Seksualitas perempuan dalam budaya patriarkhi. Muwazah, 8(1), 26-47.

Green, J. L. (2004). Uncovering collective rape: A comparative study of political sexual violence. International Journal of Sociology, 34(1), 97-116.

Hikmawati, C. L. (2017). Opresi berlapis perempuan etnis Tionghoa: Pemerkosaan massal terhadap perempuan etnis Tionghoa dalam Tragedi Mei 1998 di Jakarta. Jurnal Politik, 2(2), 337-364. https://doi. org/10.7454/jp.v2i2.76.

Kartika, S. (2003). Kritik sastra feminis: Sebuah jalan menuju kesetaraan melalui dunia sastra. Jurnal Perempuan untuk Pencerahan dan Kesetaraan, 30.

Novitasari, M. (2018). Diskriminasi gender dalam produk budaya populer (Analisis wacana Sara Mills pada novel 'Entrok'). Jurnal Semiotika, 12(2), 151-167. http://dx.doi.org/10.30813/s:jk.v12i2.1715.

Sakinah, R. M. N. (2012). Identitas dan isu politik pada tokoh perempuan Putri Cina dan Giok Tien dalam novel 'Putri Cina' karya Shindunata (Kajian Poskolonial). Apollo Project: Jurnal Ilmiah Program Studi Sastra Inggris, 1(1), 24-29 https://doi.org/10.34010/apollo. v1i1.141.

Sakinah, R. M. N. (2014). Pandangan orientalis terhadap identitas dan isu politik tokoh perempuan dalam 'Putri Cina'. Patanjala: Jurnal Penelitian
Sejarah dan Budaya, 6(2), 209-222. http://dx.doi. org/10.30959/ptj.v6i2.195.

Saputra, H. (2011). Menelisik Putri Cina, mengeluh kesahkan multikulturalisme. Kajian Sastra: Jurnal Bidang Kebahasaan dan Kesusastraan, 35(1), 1-14.

Sindhunata. (2007). Putri Cina. Jakarta: PT Gramedia Pustaka Utama.

Spivak, G.C. (1988). Can the subaltern speak? In C. Nelson \& L. Grossberg (Eds.), Marxism and the Interpretation of Culture (pp 271-313). Urbana: University of Illinois Press.

Suryadinata, L. (2003). Kebijakan negara Indonesia terhadap etnik Tionghoa: Dari asimilasi ke multikulturalisme? Jurnal Antropologi Indonesia, 71, 1-12. https://doi. org/10.7454/ai.v0i71.3464.

Udasmoro, W (Ed.). (2018). Hamparan wacana: Dari praktik ideologi, media hingga kritik poskolonial. Yogyakarta: Penerbit Ombak.

Udasmoro, W. (2020). Gerak kuasa: Politik wacana, identitas, dan ruang/waktu dalam bingkai kajian budaya dan media. Jakarta: KPG (Kepustakaan Populer Gramedia).

Wijayanti, C. T., Hadi, P. K., \& Furinawati, Y. (2018). Dominasi laki-laki atas perempuan terhadap kehidupan seksual dalam novel 'Lelaki Harimau' karya Eka Kurniawan. Widyabrasta: Jurnal Ilmiah Pembelajaran Bahasa dan Sastra Indonesia, 6(1), 52-61.

Yasin, M. (2016). Sastra dan wacana seksualitas: Sebuah dominasi maskulinitas perempuan di Indonesia. Tasamuh, 13(2), 197-214.

Zamzuri, A. (2012). Pribumi vs asing: Kajian poskolonial terhadap 'Putri Cina' karya Sindhunata. Widyaparwa, 40(1), 25-32. 